\title{
Coccolithophores and calcite saturation state in the Baltic and Black Seas
}

\author{
T. Tyrrell ${ }^{1}$, B. Schneider ${ }^{2}$, A. Charalampopoulou ${ }^{1}$, and U. Riebesell ${ }^{3}$ \\ ${ }^{1}$ National Oceanography Centre, Southampton University, European Way, Southampton SO14 3ZH, UK \\ ${ }^{2}$ Institut für Ostseeforschung Warnemünde, Seestrasse 15, 18119 Rostock, Germany \\ ${ }^{3}$ Leibniz-Institute of Marine Sciences, IFM-GEOMAR, Duesternbrooker Weg 20, 24105 Kiel, Germany
}

Received: 25 September 2007 - Published in Biogeosciences Discuss.: 10 October 2007

Revised: 30 January 2008 - Accepted: 27 February 2008 - Published: 1 April 2008

\begin{abstract}
The Baltic and Black Seas are both brackish, that is to say both have salinities intermediate between freshwater and seawater. The coccolithophore Emiliania huxleyi is abundant in one, the Black Sea, but absent from the other, the Baltic Sea. Here we present summertime coccolithophore measurements confirming this difference, as well as data on the calcium carbonate saturation state of the Baltic Sea. We find that the Baltic Sea becomes undersaturated (or nearly so) in winter, with respect to both the aragonite and calcite mineral forms of $\mathrm{CaCO}_{3}$. Data for the Black Sea are more limited, but it appears to remain strongly supersaturated yearround. The absence of E. huxleyi from the Baltic Sea could therefore potentially be explained by dissolution of their coccoliths in winter, suggesting that minimum annual (wintertime) saturation states could be most important in determining future ocean acidification impacts. In addition to this potential importance of winter saturation state, alternative explanations are also possible, either related to differences in salinity or else to differences in silicate concentrations.
\end{abstract}

\section{Introduction}

Despite many decades of research, the ecological niche for coccolithophores remains poorly understood. By analogy with diatoms, which take up dissolved silicate for construction of their silica frustules (shells), and as a consequence become uncompetitive when levels of dissolved silicate run out (Egge and Aksnes, 1992; Brzezinski et al., 1998), coccolithophores might be expected to be affected by the availability of dissolved substances from which to build their calcium

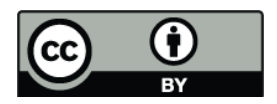

Correspondence to: $\mathrm{T}$. Tyrrell

(tt@noc.soton.ac.uk) carbonate coccoliths (shells) (Merico et al., 2006). As far as inorganic precipitation and dissolution of calcium carbonate are concerned, the tendency for these two processes to take place is governed by the saturation state:

$\Omega=\left[\mathrm{CO}_{3}^{2-}\right] \cdot\left[\mathrm{Ca}^{2+}\right] / K_{s p}$

with inorganic precipitation increasingly likely and/or rapid as $\Omega$ increases further above 1.0, and dissolution increasingly likely and/or rapid as $\Omega$ decreases further below 1.0.

If biogenic calcification were to be controlled in the same way as inorganic calcification, and if coccolithophore ecological success is contingent on being able to build coccoliths (the function of coccoliths remains poorly understood) then coccolithophores will become uncompetitive when levels of carbonate ion and/or calcium ion run low. It is still unclear whether this is actually the case. Two considerations suggest otherwise: (1) coccolith formation takes place in an internal vesicle, the chemistry of which need not be intimately connected to external seawater chemistry (Brownlee and Taylor, 2004), and (2) it is unclear whether bicarbonate ion $\left(\mathrm{HCO}_{3}^{-}\right)$ or carbonate ion $\left(\mathrm{CO}_{3}^{2-}\right)$ (isotopic constraints rule out $\mathrm{CO}_{2}$ - Rost and Riebesell, 2004) is taken up as the substrate for calcification (Paasche, 2001).

This question of a possible connection between $\Omega$ and coccolithophore success is of considerable importance because of the current ongoing acidification of the oceans (Caldeira and Wicket, 2003, 2005; Orr et al., 2005). Falling pH is expected (depending on emissions of $\mathrm{CO}_{2}$ ) to lead to a halving of carbonate ion concentration by the year 2100 , compared to pre-industrial levels, and therefore to a halving of saturation state (Zeebe and Wolf-Gladrow, 2001; Caldeira and Wicket, 2005; Orr et al., 2005). Here we investigate the likely impact of acidification on coccolithophores through comparison of their success in two seas of differing saturation state.

Published by Copernicus Publications on behalf of the European Geosciences Union. 


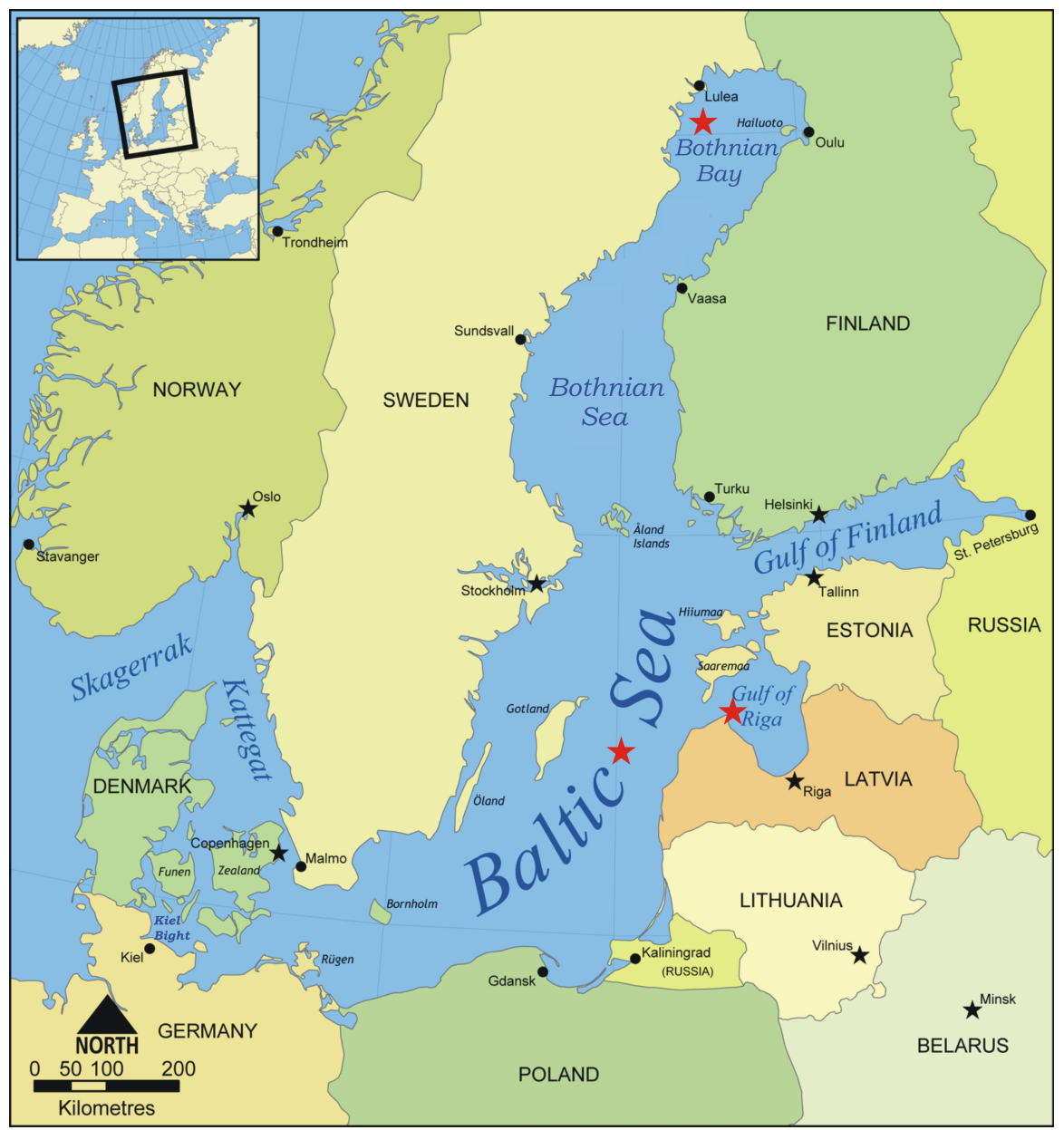

Fig. 1. Map of the Baltic Sea. Approximate locations of sampling for carbonate chemistry (cf. Fig. 3) are shown by the red stars. The central Baltic Sea (also known as the Baltic Sea proper) corresponds to the Baltic Sea east of the Kattegat and the Danish islands, south of the Bothnian Sea and west of the Gulf of Finland and the Gulf of Riga. The Gotland Sea, part of the central Baltic Sea, lies to the east of the island of Gotland. Adapted from an original map by N. Einstein.

\section{Absence of coccolithophores in the Baltic Sea}

The first ever recorded observations of coccoliths were made by Christian Gottfried Ehrenberg in 1836. They were made in the Baltic Sea, although not in the water itself but rather from examination of fossil coccoliths in samples from the cliffs of the Isle of Rugen (Siesser, 1994). This island, in the southern Baltic Sea off the north coast of Germany (Fig. 1), has distinctive white chalk cliffs, dating from the Cretaceous period when sea-levels were very much higher and the Baltic was not more or less cut off from the open sea as it is today. It is somewhat ironic that the first observations of coccoliths were made in ancient Baltic Sea sediments because today planktonic calcifiers are thought to be largely absent from the Baltic Sea. We tested this received knowledge (HELCOM, 2002) with direct targeted sampling for coccolithophores in the Baltic Sea proper (Fig. 1) during a cruise on R/V Gauss in the period 19-27 July 2006.
For each of seven stations sampled, up to 1 litre (1) of seawater was filtered through a $47 \mathrm{~mm}$ diameter $0.4 \mu \mathrm{m}$ pore size Millipore ${ }^{\circledR}$ Isopore membrane filter under low vacuum. After rinsing with alkaline water $(\mathrm{pH} \sim 9.7)$ each filter was left to air-dry. Filters were stored in dark and dry conditions until analysis, at which point a small piece (about $1 \mathrm{~cm}^{2}$ ) of each membrane filter was cut radially, placed on a stub and gold-coated. Counting of the coccospheres under a Leo 1450VP (variable pressure) scanning electron microscope (SEM) was carried out with a computer-controlled stage and a fully automated image-capturing system. The software SmartSEM V05-01 was used to capture and store all images collected for each sample along a predefined meandershaped transect. Each transect consisted of 225 view fields (total area of $2.5 \mathrm{~mm}^{2}$ ) at a magnification of $\times 3000$ and all images were stored on a CD-ROM. An example field-ofview, showing a portion of one of the filter papers as seen under the SEM, is displayed in Fig. 2. 
Despite visual examination of more than 1500 single images (fields of view), not one coccolithophore or coccolith was seen on the filter papers. Numerous pennate diatoms were observed. Many collapsed non-mineralised cells were also seen, of unknown taxonomic affiliation. The sampling location was offshore (coccolithophores tend to be more successful in offshore than in coastal locations) and the time of year was also one at which coccolithophores are found to be present in high numbers in the open North Atlantic (Brown and Yoder, 1994; Holligan et al., 1993a; Raitsos et al., 2006).

Our Baltic Sea analyses found no evidence of coccolithophores being present, in agreement with the received knowledge.

\section{Calcite saturation state in the Baltic Sea}

Coccolithophores are abundant in the sub-polar North Atlantic (e.g. Holligan et al., 1993a; Brown and Yoder, 1994; Raitsos et al., 2006), the Barents Sea (Smyth et al., 2004), the northern North Sea (Holligan et al., 1993b; Burkill et al., 2002) offshore and within the fjords of south-western Norway (e.g. Kristiansen et al., 1994) and even in the Skagerrak (Pingree et al., 1982; http://www.noc.soton.ac.uk/soes/ staff/tt/eh/pics/sat/skag2.jpg), where the Baltic Sea meets the North Sea. It is therefore somewhat puzzling that they are absent from the Baltic Sea east of the transition area to the North Sea, given that they thrive in nearby waters at similar latitudes. Low salinity of the Baltic Sea may be considered as an obvious explanation for their absence; we argue below, however, that this may not be the critical reason.

In light of the current concerns over possible consequences of ocean acidification, we also consider whether the absence from the Baltic Sea could be explained by differences in $\mathrm{CaCO}_{3}$ saturation state $(\Omega)$.

Comprehensive studies on the Baltic Sea $\mathrm{CO}_{2}$ system have been performed during past years. These investigations concentrated on surface waters and were based mainly on measurements of the $\mathrm{CO}_{2}$ partial pressure $\left(\mathrm{pCO}_{2}\right)$ and the total $\mathrm{CO}_{2}$ concentration $\left(C_{T}\right)$ (e.g. Schneider et al., 2003; Schneider and Kuss, 2004). Here we use this same data (Gotland Sea) as well as other data presented here for the first time (Gulf of Riga, Bothnian Bay) to determine the calcite/aragonite saturation. The $\mathrm{CO}_{3}^{2-}$ concentrations were calculated from the $\mathrm{pCO}_{2}$ and $C_{T}$ data using the equilibrium constants for the marine $\mathrm{CO}_{2}$ system proposed by Roy et al. (1993) (the only set of constants determined down to salinity of 5) and the $\mathrm{CO}_{2}$ solubility constants given by Weiss (1974). The $\mathrm{Ca}^{2+}$ concentrations ( $\mathrm{mmol} \mathrm{kg}^{-1}$ ) were estimated from $\mathrm{Ca} / \mathrm{salinity}$ relationships for the central Baltic Sea (Dyrssen, 1993: $\mathrm{Ca}=0.331 \times S+0.392$ ) and for the Bothnian Bay in the uppermost north of the Baltic Sea (Gripenberg, 1960: $\mathrm{Ca}=0.375 \times S+0.0368)$. Although magnesium is less abundant in the Baltic Sea than in oceanic seawater, the molar $\mathrm{Mg} / \mathrm{Ca}$ ratios are similar ( $\sim 5$ in both cases, Gunnars

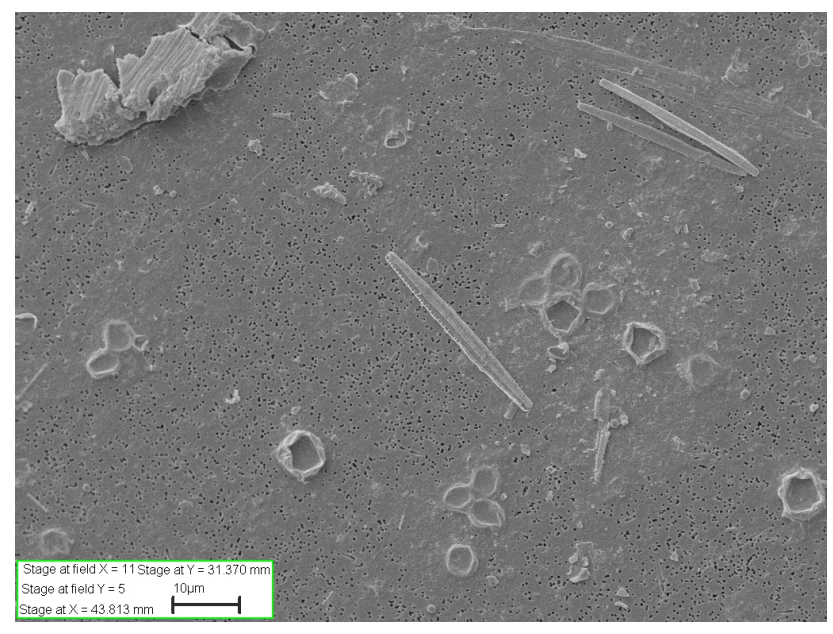

Fig. 2. Typical SEM field-of-view from samples collected in the Baltic Sea proper during July 2006.

et al., 2004 and references therein) and therefore we estimate a minimal effect on $K_{s p}$. To calculate the solubility products for calcite and aragonite as a function of salinity and temperature, we used the algorithms given by Mucci (1983). The calcite/aragonite saturation was then determined on the basis of $\mathrm{CO}_{2}$ measurements performed in 1997 (November) and 2001 (March, May, July) in a station grid (26 stations) in the central Baltic Sea east of the island of Gotland (Gotland Sea, Fig. 1). Data were also collected in the Gulf of Riga (March 2000) and the Bothnian Bay (March 2006). The results (Fig. 3, Table. 1) indicate a distinct seasonality of the mean $\Omega$ in the central Baltic Sea for both calcite and aragonite. The minimum is observed in March during the culmination of the convective mixing with $\Omega$ of about 1.0 and 0.6 for calcite and aragonite, respectively.

\subsection{Cause of low wintertime $\Omega$}

Such low winter values do not occur in oceanic surface waters at similar latitudes, which are significantly oversaturated with regard to both calcite and aragonite throughout the year. This is a consequence of lower $\mathrm{CO}_{3}^{2-}$ and $\mathrm{Ca}^{2+}$ concentrations in the central Baltic Sea that lower $\Omega$ (see Eq. 1) despite the decrease of $K_{s p}$ by a factor of about 7 at a salinity of 7 (Mucci, 1983). The state of the marine $\mathrm{CO}_{2}$ system is controlled by a complex interplay between physical and biogeochemical variables. Lower salinities and winter temperatures in the Baltic Sea $\left(S \approx 7, T \approx 0^{\circ} \mathrm{C}\right)$ lead to dissociation constants for carbonic acid that are considerably below those in mid-latitude oceanic regions $\left(S \approx 35, T \approx 8^{\circ} \mathrm{C}\right)$ and thus cause reduced $\mathrm{CO}_{3}^{2-}$ concentrations (Baltic Proper average of $126 \mu \mathrm{mol} \mathrm{kg}^{-1}$ in summer, $29 \mu \mathrm{mol} \mathrm{kg}{ }^{-1}$ in winter). This effect is compounded by the alkalinity that in most regions of the Baltic Sea is lower $\left(\approx 1600 \mu\right.$ Equiv kg $^{-1}$ at $S=7$; Fig. 5a of Hjalmarsson et al., 2008) than in oceanic surface 
Table 1. Further information on carbonate chemistry sampling. $C_{T}$ and $\mathrm{pCO}_{2}$ were measured, and other carbonate chemistry parameters calculated from them. Performing the calculations with a different set of dissociation constants not developed for low salinity conditions (Mehrbach et al., 1973) led to differences in $\mathrm{CO}_{3}$ of about $0.9 \mu \mathrm{mol} / \mathrm{kg}$ at low $\mathrm{CO}_{3}$ (Bothnian Bay in March) and about $2 \mu \mathrm{mol} / \mathrm{kg}$ at high $\mathrm{CO}_{3}$ (Gotland Sea in July). Relative differences in $\Omega$ are about $15 \%$ at low values in the Bothnian Bay in March and about $1 \%$ during summer oversaturation in the Gotland Sea in July. $\mathrm{pH}$ is on the total $\mathrm{pH}$ scale.

\begin{tabular}{|c|c|c|c|c|c|c|c|c|c|c|}
\hline Sea Area & $\begin{array}{c}\text { Number of } \\
\text { Stations }\end{array}$ & Season & Salinity & $\begin{array}{c}\text { Temperature } \\
{ }^{\circ} \mathrm{C}\end{array}$ & $\begin{array}{c}\mathrm{C}_{T} \\
\mu \mathrm{mol} / \mathrm{kg}\end{array}$ & $\begin{array}{l}\mathrm{pCO}_{2} \\
\mu \mathrm{atm}\end{array}$ & $\mathrm{pH}$ & $\begin{array}{c}\mathrm{CO}_{3} \\
\mu \mathrm{mol} / \mathrm{kg}\end{array}$ & $\begin{array}{c}\Omega \\
\text { calcite }\end{array}$ & $\begin{array}{c}\Omega \\
\text { aragonite }\end{array}$ \\
\hline Gotland Sea & 20 & March 2001 & 7.16 & 2.71 & 1587 & 407 & 7.99 & 28.8 & 1.03 & 0.57 \\
\hline Gotland Sea & 25 & May 2001 & 6.88 & 6.42 & 1526 & 164 & 8.38 & 78.4 & 2.86 & 1.57 \\
\hline Gotland Sea & 26 & July 2001 & 6.60 & 18.91 & 1441 & 156 & 8.42 & 126.2 & 4.94 & 2.78 \\
\hline Gotland Sea & 26 & Nov 1997 & 6.72 & 9.89 & 1551 & 421 & 8.01 & 38.6 & 1.44 & 0.79 \\
\hline Gulf of Riga & 5 & March 2000 & 5.81 & 0.89 & 1908 & 403 & 8.07 & 36.3 & 1.33 & 0.72 \\
\hline Bothnian Bay & 3 & March 2006 & 3.23 & 0.87 & 873 & 542 & 7.60 & 5.3 & 0.18 & 0.10 \\
\hline
\end{tabular}

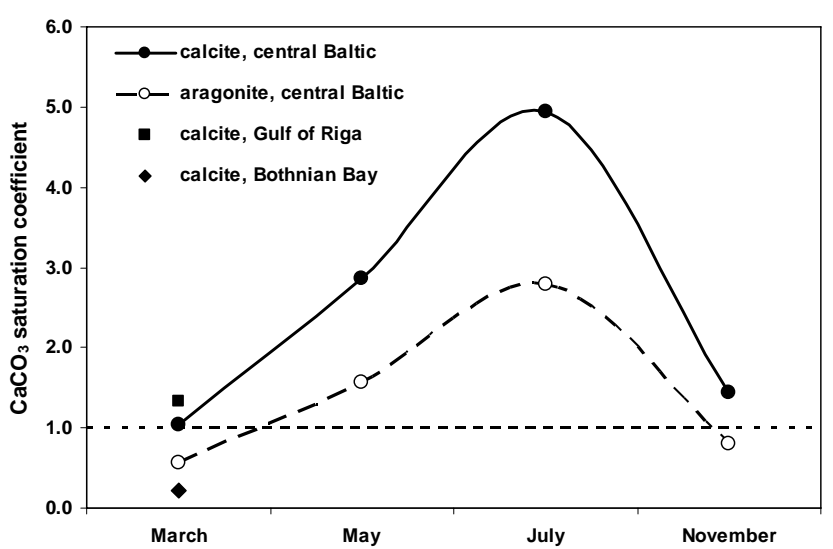

Fig. 3. Seasonality of the calcite and aragonite saturation in the central Baltic Sea (each point represents the average of 20 or more adjacent measurements), and calcite saturation in both the Gulf of Riga and the Bothnian Bay during March. See Fig. 1 for sampling locations.

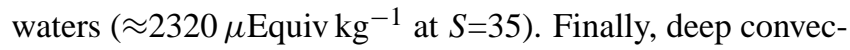
tive mixing during winter generates surface $\mathrm{CO}_{2}$ partial pressures in the Baltic Sea that are above $400 \mu$ atm whereas $\mathrm{CO}_{2}$ in comparable oceanic waters is close to equilibrium with the atmosphere. In total, these differences produce $\mathrm{CO}_{3}^{2-}$ concentrations in the Baltic Sea surface water that during winter are about 5 times lower than those in the North Atlantic $\left(\approx 140 \mu \mathrm{mol} \mathrm{kg}^{-1}\right)$. Additionally, $\mathrm{Ca}^{2+}$ concentrations in the Baltic Sea $\left(\approx 3 \mathrm{mmol} \mathrm{kg}^{-1}\right.$ at $\left.S=7\right)$ are about 4 -fold lower than in oceanic waters and further reduce $\Omega$ to values of about 1 for calcite and 0.5 for aragonite.

\subsection{Cause of large seasonal variation in $\Omega$}

The seasonal amplitude of $\Omega$ is also unusually high in the Baltic Sea (range of about 4, Fig. 3) in comparison to open ocean locations (range of between 1 and 2: Findlay et al., 2007). This is a consequence of contrasting seasonality of temperature, differences in water chemistry, and differences in the dominant phytoplankton.

In the Baltic Sea the temperature difference between the minimum in February and the maximum in July is about $20^{\circ} \mathrm{C}$ whereas the corresponding difference is less than half as great as this in mid-latitude oceanic waters. The consequence is a larger seasonality of the $\mathrm{CO}_{3}^{2-}$ concentration in the Baltic Sea.

Additionally, the removal and addition of $\mathrm{CO}_{2}$ by production and decomposition of organic matter affects saturation states much more strongly in the Baltic Sea. Rather similar phosphate drawdowns occur from winter to summer $\left(0.5 \mu \mathrm{mol} \mathrm{kg}^{-1}\right)$ in the Baltic Proper and in the North Atlantic at $50-60^{\circ} \mathrm{N}, 20^{\circ} \mathrm{W}$ (Tyrrell and Taylor, 1996). Assuming similar $\mathrm{C}_{\text {org }}: \mathrm{P}$ at the two locations, $\mathrm{PO}_{4}$ removal would be accompanied by similar drawdowns of $C_{T}$. According to Eq. (1) above, saturation state is equal to $\left(\left[\mathrm{Ca}^{2+}\right] / K_{s p}\right)$ multiplied by $\left[\mathrm{CO}_{3}^{2-}\right]$. As just discussed, $K_{s p}$ is about 7-fold lower in the Baltic, but $\left[\mathrm{Ca}^{2+}\right]$ is only about 4-fold lower. Therefore, because the term $\left(\left[\mathrm{Ca}^{2+}\right] / K_{s p}\right)$ in the Baltic is almost double the value in the Atlantic, similar absolute changes in $\left[\mathrm{CO}_{3}^{2-}\right]$ (e.g. driven by carbon removal during spring blooms) produce much greater absolute changes in saturation state in the Baltic. By a similar reasoning, the effect of anthropogenic $\mathrm{CO}_{2}$ on seawater $\Omega$ will be much stronger in the Baltic Sea than in oceanic waters.

$\mathrm{C}_{\text {org }}: \mathrm{P}$ is, however, not similar at the two locations, contrary to the assumption above. In the Baltic Sea about $50 \%$ of the phosphate is used by nitrogen-fixing cyanobacteria 
because there is a high excess of phosphate over nitrate (relative to the Redfield ratio) in the Baltic Sea winter water. Several studies have shown that cyanobacteria produce organic matter with high $\mathrm{C}_{\text {org }}: P$ ratios (e.g. Schneider et al., 2003: about 300 and Larsson et al., 2001: about 400, compared to the Redfield ratio of 106), thus removing much more $C_{T}$, leading to greater seasonality in $\left[\mathrm{CO}_{3}^{2-}\right]$.

\subsection{Cause of regional variability in $\Omega$}

The previous considerations referred to the central Baltic Sea which can be considered as a mixing chamber for inflowing water from the North Sea and from the various rivers. Differing conditions with regard to the state of the $\mathrm{CO}_{2}$ system can be found in semi-enclosed estuarine areas of individual rivers. A prominent example is the Gulf of Riga where water from the River Daugava and from the central Baltic Sea are mixed. River Daugava water originates from the limestonerich watershed area in continental Europe and has alkalinities of up to $3000 \mu \mathrm{mol} \mathrm{kg}^{-1}$ (Hjalmarsson et al., 2008). As a consequence, increased $\mathrm{CO}_{3}^{2-}$ concentrations are observed in most areas of the Gulf and cause calcite oversaturation (Fig. 3: $\Omega=1.3$ at $S \approx 5$ ) even during wintertime. A contrasting example is the Bothnian Bay which is influenced by rivers that have crossed the Scandinavian shield. This watershed area consists mainly of igneous rocks which hardly contribute to river water alkalinity $\left(200 \mu \mathrm{mol} \mathrm{kg}^{-1}\right)$ (Hjalmarsson et al., 2008). Hence, the Gulf of Bothnia water is characterized by low $\mathrm{CO}_{3}^{2-}$ concentrations resulting in a distinct calcite undersaturation during wintertime (Fig. 3: $\Omega=0.2$ at $S \approx 5$ ).

\section{Discussion}

4.1 Comparison to other phytoplankton sampling in the Baltic Sea

We checked the findings of our work, and of HELCOMM (2002), against other work. In his book on Baltic Sea algae, Helmut Pankow (1990) lists 9 genera of coccolithophores occurring in the Baltic Sea (Acanthoica, Balaniger, Calciopappus, Discosphaera, Emiliana, Hymenomonas, Pappomonas, Papposphaera, and Trigonapsis). For most of these genera, the occurrence is limited to the Danish Seas, which is likely to reflect an inflow from North Sea waters. Emiliania huxleyi is also reported from the Kiel Bight, but again this may correspond to inflow of North Sea water. No indication is given of abundances or frequencies of occurrence. In terms of waters unaffected by Atlantic influence, Pleurochrysis carterae, Hymenomonas roseola, Balaniger balticus and Pappomonas virgulosa have been found in the northeastern Baltic Sea. In his comprehensive listing of Baltic Sea phytoplankton species, Hällfors (2004) lists only four species (Coccolithus pelagicus, Pleurochrysis carterae, Pappomonas lepida and Balaniger balticus) as occurring in the
Baltic Sea (excluding the Kiel Bight (Fig. 1), where many more species have been seen). C. pelagicus is unusual in that it is the only coccolithophore species that has been seen in the Baltic Sea proper; it has also been found in the Bothnian Sea and Bothnian Bay as well as in the Gulf of Finland. Interestingly, in laboratory culture experiments $C$. pelagicus appears unusually robust in as much as its calcification is hardly affected by the low saturation states associated with high $\mathrm{CO}_{2}$ (Langer et al., 2006).

Samples taken in Kiel fjord occasionally contain individual cells of coccolithophores, but always in very low numbers (U. Sommer and A. Stuhr, personal communication). In routine weekly phytoplankton countings by Jeanette Goebel (personal communication) of the Landesamt für Natur und Umwelt in Schleswig-Holstein, blooms of E. huxleyi were recorded in the mid 1980s and again in the early 1990s. These were probably confined to the Danish waters and the Kiel Bight.

An examination of the literature thus slightly modifies the conclusion we obtained from our own sampling. Rather than being completely absent, it seems that coccolithophores are instead occasionally present (although extremely scarce) in the Baltic Sea. To our knowledge there have never been any observations of coccolithophore blooms or high abundances in the Baltic Sea proper, although coccolithophores may occasionally be missed due to the common practice of preservation with acidic Lugols (which dissolves coccoliths). They have always been found to be either completely absent or else a very minor component of the community. The only exception is in the Danish Seas and Kiel Bight, in waters potentially affected by the inflow from the North Sea.

\subsection{Comparison to other carbonate system measurements}

\subsubsection{Global}

The GLODAP dataset (Key et al., 2004) is a global dataset of carbonate chemistry ( $C_{T}$ and Alkalinity) measurements from open ocean cruises, much of it collected as part of the World Ocean Circulation Experiment (WOCE) and Joint Global Ocean Flux Study (JGOFS) programmes during the 1990s. The data points are combined together to give a global distribution of the carbonate chemistry. Seasonal cycles are not considered. Only an average annual distribution is presented, and possible biases due to sampling of many locations at only one time of year (e.g. scarcity of winter measurements at high latitudes) are ignored. For the open North Atlantic at $60^{\circ} \mathrm{N}$, $20^{\circ} \mathrm{W}$ (at a similar latitude to the Baltic Sea proper), the carbonate ion concentration derived from the GLODAP dataset (together with temperature and salinity taken from Levitus climatologies) is about $170 \mu \mathrm{mol} \mathrm{kg}^{-1}$, leading to a calcite saturation state of about 4 . This compares to global $\left(70^{\circ} \mathrm{S}-\right.$ $60^{\circ} \mathrm{N}$ ) ranges of about $80-300 \mu \mathrm{mol} \mathrm{kg}^{-1}$ for carbonate ion (Orr et al., 2005) and about 2-7 for calcite saturation state. 
4.2.2 High-latitude seas exchanging freely with the open ocean

A combined ecosystem/carbon chemistry model of the eastern Bering Sea (Merico et al., 2006) first examined the seasonal cycle of carbonate chemistry. At this highlatitude site $\left(56.8^{\circ} \mathrm{N}, 164^{\circ} \mathrm{W}\right)$, the modelling suggested considerable seasonal variation in both carbonate ion (100 $\left.150 \mu \mathrm{mol} \mathrm{kg}^{-1}\right)$ and calcite saturation state (2.5-3.5). The values of both parameters were found to be low in wintertime, to rise sharply at the time of the spring blooms, and then to stay at high values through the summer period until values decline in autumn as mixing depths increase and deep waters are mixed up into the surface. It was not possible to fully test this model prediction against data from the eastern Bering Sea. Seasonal in-situ data are, however, available from the Norwegian Sea shelf break (Ocean Weather Station "Mike", $66^{\circ} \mathrm{N}, 2^{\circ} \mathrm{E}$ ), and agree in outline with the model predictions for the eastern Bering Sea. The Norwegian Sea data show a range in carbonate ion of $130-180 \mu \mathrm{mol} \mathrm{kg}-1$ and in calcite saturation state of 3-4, again with a minimum in winter and a maximum in summer (Findlay et al., 2007). The seasonal pattern is caused by the spring diatom blooms, because the intense $C_{T}$ removal has the side-effect of driving up carbonate ion concentrations (Merico et al., 2006). The seasonal variation in SST is of only second-order importance in determining the seasonal cycle of carbonate ion in the eastern Bering Sea (Merico et al., 2006).

From this comparison to other data it appears that the Baltic Sea exhibits a similar general seasonal pattern to the Norwegian Sea and eastern Bering Sea, in terms of carbonate system parameters. The amplitude of the seasonal range is, however, much larger than in the open-sea locations. Summertime saturation states are high, but wintertime saturation states are extremely low, lower even than in polar oceanic waters. The greater seasonal amplitude derives from the unusual chemistry of the Baltic Sea and the large annual temperature range.

\subsubsection{The Black Sea}

There is less data from which to calculate $\mathrm{CaCO}_{3}$ saturation states in the Black Sea. Goyet et al. (1991) measured the carbonate chemistry at a few stations in the Black Sea in 1988, during cruise 134 of R. V. Knorr. Although the measurements were made at the same time of year (June) as the Emiliania huxleyi blooms occur, they were made many years before the first satellite observations of Emiliania huxleyi blooms in the Black Sea (Cokacar et al., 2004). However, the presence of a thick layer of coccoliths in surface sediments of the Black Sea (Hay, 1988) shows that coccolithophores have also been present before the last few years. Total inorganic carbon $\left(C_{T}\right)$ and total alkalinity $\left(A_{T}\right)$ were measured, and other carbonate system parameters derived from them. Simultaneous surface-layer measurements of both $C_{T}$ and $A_{T}$ were made at only one offshore station, station 6 , at $43^{\circ} \mathrm{N}, 34^{\circ} \mathrm{E}$ in the central Black Sea. At this station the derived surface water concentration of carbonate ion was $250 \mu \mathrm{mol} \mathrm{kg}^{-1}$, and calcite saturation state was 7.5.

As discussed above, the seasonal amplitude in saturation state is governed in large part by the intensity of winter mixing (which stirs up nutrients), the consequent seasonal drawdowns of nitrate and phosphate (actually the seasonal drawdown of $C_{T}$ is critical, but is related to the others through elemental stoichiometry of organic matter), and therefore to the size of the spring blooms. Because it is closer to the equator than is the Baltic Sea, there is a rather muted seasonal cycle in comparison. Only a modest amount of winter mixing and nutrient stirring takes place in winter, with, in consequence, winter/spring blooms that are of small magnitude in relation to those in the Baltic Sea (Oguz et al., 2001).

There is only limited data to confirm relatively high wintertime saturation states, but it can in any case be inferred on the following grounds: (1) relatively high summertime values, and (2) low-amplitude seasonal variation in phytoplankton and nutrients, which will drive only a low amplitude seasonal variation in $\left[\mathrm{CO}_{3}^{2-}\right]$ and $\Omega$ (Merico et al., 2006). Surface measurements in May 2001, in offshore waters of the southwestern Black Sea near to the Bosporus (Hiscock and Millero, 2006), gave rather similar results to Goyet et al. (1991) for $C_{T}, A_{T}$ and calcite saturation state (again about 7.5)

4.3 No calcifiers because of winter $\mathrm{CaCO}_{3}$ undersaturation?

$\mathrm{CaCO}_{3}$ saturation state generally declines with increasing latitude (Orr et al., 2005; Caldeira and Wickett, 2005), such that undersaturation of surface open ocean waters will be reached first in polar waters, as fossil fuel emissions intensify ocean acidification in the future. However, although lower than summertime values, wintertime saturation states are still considerably supersaturated (i.e. values significantly greater than 1) in: (a) the open Atlantic south of Iceland (calculated from data in Takahashi et al., 1985), (b) in the Norwegian Sea (Findlay et al., 2007), and (c) in the eastern Bering Sea according to model calculations (Merico et al., 2006).

The Baltic Sea is therefore anomalous in comparison to oceanic sites at similar latitudes in that wintertime surface waters are distinctly undersaturated with respect to aragonite and borderline undersaturated with respect to calcite. Surface saturation states in summer, on the other hand, are higher than in comparable oceanic locations where coccolithophores thrive. We propose that the low wintertime saturation states may be the critical difference underlying the exclusion of coccolithophores from the Baltic Sea proper. If coccolithophores are unable to prevent dissolution of their coccoliths in undersaturated waters, and if the coccoliths are critical to their ecological competitiveness (their function is still unclear: Young, 1984), then an inability to survive 
through the winter would explain their absence in the Baltic Sea proper.

\subsection{Alternative possible explanations}

The ecological niche for E. huxleyi, and the factors responsible for blooms developing at some times and places but not others, have recently been reviewed (Tyrrell and Merico, 2004; Balch, 2004; Rost and Riebesell, 2004; Paasche, 2001), but are still relatively poorly understood.

\subsubsection{Salinity}

At first sight the most obvious reason why coccolithophores might be excluded from the Baltic Sea is the low salinity compared to oceanic waters. The surface water salinity in the eastern Gotland Sea, where our sampling was carried out, is about 7. Salinity varies considerably across the Baltic Sea: areas furthest from the North Sea (Bothnian Bay, Gulf of Finland) have lowest salinities (often less than 5), and salinity then increases towards the North Sea, eventually reaching values greater than 18 in the Kattegat, on the way out to the North Sea (Janssen et al., 1999).

On the other hand, E. huxleyi "is one of the most euryhaline and eurythermal coccolithophore species" (Winter et al., 1994). E. huxleyi occurs at bloom concentrations in the central Black Sea (e.g. Fig. 4; Cokacar et al., 2001), at salinities of 18-19, approximately half the average oceanic value of $\sim 35$. E. huxleyi has also been recorded from the northeastern Black Sea at salinity 15-17 (Mikaelyan et al., 2005) and from the Sea of Azov (Pitsyk, 1963) at salinity $\sim 11$ (Matishov et al., 2006; http://www.nodc.noaa.gov/OC5/AZOV2006/start. html). In both the Black Sea and the Baltic Sea inflows of deep saline water occur, but surface waters typically flow out to the North and Mediterranean Seas respectively.

In culture experiments it was found that one coastal and two oceanic strains of $E$. huxleyi were able to survive when grown at a salinity of 15 , whereas another oceanic strain perished (Brand, 1984). Only the coastal strain grew at all rapidly at this salinity. One oceanic strain plus one coastal strain were tested at a salinity of 5 , but neither survived (Brand, 1984). At face value these culture experiments suggest a lower salinity tolerance somewhere between 5 and 15 . However, only a few strains were tested and others may be more tolerant of low salinities.

Because the salinity of the central Black Sea $(\sim 18)$ is significantly higher than that of the Baltic Sea proper $(\sim 7)$, salinity remains a possible explanation of the data discussed so far, although E. huxleyi success in the Sea of Azov $(\sim 11)$ makes this less likely.

\subsubsection{Temperature}

Coccolithophores are on average most successful (in terms of diversity and fraction of the total phytoplankton community) in warm, oligotrophic, low-latitude waters (Winter et

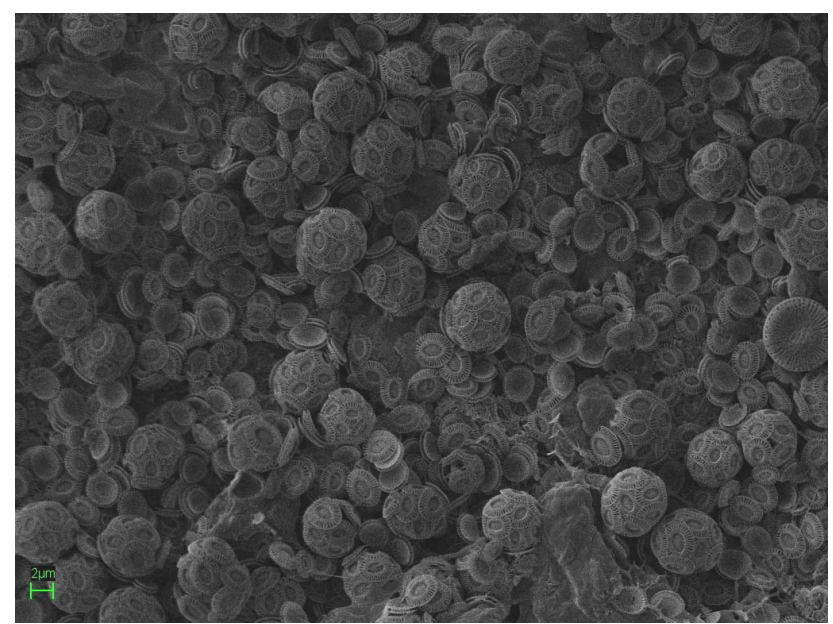

Fig. 4. An SEM image from $\sim\left(28.5^{\circ} \mathrm{E}, 42.8^{\circ} \mathrm{N}\right)$ in the Black Sea June 2006. E. huxleyi concentrations of 0.8-2.6 million cells per litre were calculated. Methods were as described earlier for the Baltic Sea, with the exception that up to 3 litres were filtered in the Black Sea, and that $0.45 \mu \mathrm{m}$ nitrocellulose filter papers were used.

al., 1994). It has been suggested that temperature itself plays a direct role in the success of the group, although there is little hard data in support of this contention. Emiliania huxleyi thrives even in the relatively cold waters of the North Atlantic south of Iceland, the Patagonian Shelf and even the Barents Sea (Smyth et al., 2004); in the latter location monthly average temperatures vary between $\sim 2^{\circ} \mathrm{C}$ in winter and $\sim 8^{\circ} \mathrm{C}$ in summer (http://www.nodc.noaa.gov/OC5/ barsea/barindex1.html). Although the Black Sea is indeed warmer than the Baltic Sea, we do not consider this as a likely reason for the difference in success between the two seas. Wintertime temperatures in the Baltic Sea proper (e.g. $\sim 0^{\circ} \mathrm{C}$ ) are not very different from those in the Barents Sea, whereas summertime temperatures in the Baltic proper (e.g. $\sim 20^{\circ} \mathrm{C}$ ) are in fact much warmer than those in the Barents Sea.

\subsubsection{Light}

Blooms of E. huxleyi always occur in shallow mixed layers of maximum depth 20 or $30 \mathrm{~m}$ (Nanninga and Tyrrell, 1996; Tyrrell and Merico, 2004 and references therein); high light intensities appear to be a requirement for the development of E. huxleyi blooms (Nanninga and Tyrrell, 1996). Although the Black Sea has shallow mixed layers in summer, the same is also true for the Baltic Sea proper, in which a summer pycnocline is typically present at about $10-20 \mathrm{~m}$ depth (e.g. Larsson et al., 2001). We therefore discount a difference in light levels as an explanation for the differences in E. huxleyi abundance. 


\subsubsection{Silicate}

Diatoms have faster growth rates than other phytoplankton of similar size (Furnas, 1991) and, if silicate is available, typically outcompete other phytoplankton functional types. They form the major part of blooms in eutrophic locations: spring blooms in temperate latitudes, blooms near river mouths, and blooms in recently upwelled water. It is possible that the ecological niche for coccolithophores may therefore be defined in part by the conditions required to exclude the competitively superior diatoms, i.e. low concentrations of dissolved silicate in conjunction with non-limiting concentrations of other essential nutrients (Tyrrell and Merico, 2004).

Scarcity of silicate starts to become limiting to silica production and diatom growth at concentrations below about $3 \mu \mathrm{mol} \mathrm{kg}^{-1}$ (Brzezinski et al., 1998, 2005). Levels of silicate in summer were originally greater than this several decades ago but have subsequently declined, in both the Baltic Sea (Papush and Danielsson, 2006; Rahm et al., 1996) and in the Black Sea (Humborg et al., 1997; Konovalov and Murray, 2001), probably because of river damming (e.g. Humborg et al., 1997, 2006) and eutrophication (e.g. Papush and Danielsson, 2006). At the present time in the Black Sea, summer silicate levels are sufficiently low as to potentially exclude diatoms from dominance (Humborg et al., 1997; Konovalov and Murray, 2001). In the Baltic Sea proper, on the other hand, although levels of silicate in the summer are lower than in the winter (Wulff and Rahm, 1988), it appears that spring blooms consume only a fraction of the winter silicate, leaving much behind to persist through into the summer (Wasmund et al., 1998). Year-round availability of dissolved silicate in the Baltic Sea might therefore be a plausible explanation for why coccolithophores have been unable to colonise it. However, given that the Black Sea appears to have only recently become silicate-poor in summer (Humborg et al., 1997; Konovalov and Murray, 2001), whereas the sediments demonstrate a much longer record of Emiliania huxleyi success (Coolen et al., 2006; Hay, 1988; Bukry, 1974), perhaps high levels of silicate are not automatically prohibitive to coccolithophore success.

\section{Conclusions}

From the data presented here, we suggest that the presence of the coccolithophore Emiliania huxleyi in the Black Sea but not the Baltic Sea could be attributed to the very low winter-time saturation states in the surface Baltic Sea (either at or below the threshold for undersaturation, for calcite and aragonite, respectively). Alternative explanations relate to lower salinity in the Baltic Sea, or to higher silicate concentrations. These findings have potential implications for the fate of coccolithophores under ocean acidification, although more information is needed from environments where saturation states are low but salinity is high and/or silicate is low.
Our study highlights the possible significance of minimum annual (wintertime) saturation states in determining success of planktonic calcifiers.

Acknowledgements. We would like to thank S. Trinkler, G. Nausch and J. Waniek for collection of samples in the Baltic Sea, and J.-F. Berthon and E. E. Develi for collection of samples in the Black Sea.

Edited by: J. Middelburg

\section{References}

Balch, W. M.: Re-evaluation of the physiological ecology of coccolithophores, in: Coccolithophores: from molecular processes to global impact, edited by: Thierstein, H. R. and Young, J. R., Springer, Berlin, 165-190, 2004.

Balch, W. M., Holligan, P. M., Ackleson, S. G., and Voss, K. J.: Biological and Optical-Properties of Mesoscale Coccolithophore Blooms in the Gulf of Maine, Limnol. Oceanogr., 36(4), 629643, 1991.

Brand, L. E.: The salinity tolerance of forty-six marine phytoplankton isolates, Estuarine, Coastal and Shelf Science, 18, 543-556, 1984.

Brown, C. W. and Yoder, J. A.: Coccolithophorid Blooms in the Global Ocean, J. Geophys. Res.-Oceans, 99(C4), 7467-7482, 1994.

Brownlee, C. and Taylor, A.: Calcification in coccolithophores: A cellular perspective, in: Coccolithophores: from molecular processes to global impact, edited by: Thierstein, H. R. and Young, J. R., Springer, Berlin, 31-50, 2004.

Brzezinski, M. A., Jones, J. L., and Demarest, M. S.: Control of silica production by iron and silicic acid during the Southern Ocean Iron Experiment (SOFeX), Limnol. Oceanogr., 50(3), 810-824, 2005.

Brzezinski, M. A., Villareal, T. A., and Lipschultz, F.: Silica production and the contribution of diatoms to new and primary production in the central North Pacific, Mar. Ecol.-Prog. Ser., 167, 89-104, 1998.

Bukry, D.: Coccoliths as paleosalinity indicators - evidence from Black Sea, in: The Black Sea - Geology, Chemistry, and Biology, edited by: Degens, E. T. and Ross, D. A., American Association of Petroleum Geologists, Oklahoma, 353-362, 1974.

Burkill, P. H., Archer, S. D., Robinson, C., et al.: Dimethyl sulphide biogeochemistry within a coccolithophore bloom (DISCO): an overview, Deep-Sea Res. II, 49(15), 2863-2885, 2002.

Caldeira, K. and Wickett, M. E.: Anthropogenic carbon and ocean pH, Nature, 425(6956), 365-365, 2003.

Caldeira, K. and Wickett, M. E.: Ocean model predictions of chemistry changes from carbon dioxide emissions to the atmosphere and ocean, J. Geophys. Res.-Oceans, 110(C9), C09504, doi:10.1029/2004JC002671, 2005.

Cokacar, T., Kubilay, N., and Oguz, T.: Structure of Emiliania huxleyi blooms in the Black Sea surface waters as detected by SeaWIFS imagery, Geophys. Res. Lett., 28, 4607-4610, 2001.

Coolen, M. J. L., Boere, A., Abbas, B., et al.: Ancient DNA derived from alkenone-biosynthesizing haptophytes and other algae in Holocene sediments from the Black Sea, Paleoceanography, 21(1), PA1005, doi:10.1029/2005PA001188, 2006. 
Dyrssen, D.: The Baltic-Kattegat-Skagerrak Estuarine System, Estuaries, 16(3A), 446-452, 1993.

Egge, J. K. and Aksnes, D. L.: Silicate as Regulating Nutrient in Phytoplankton Competition, Mar. Ecol.-Prog. Ser., 83(2-3), 281-289, 1992.

Ehrenberg, C. G.: Bemerkungen uber feste mikroscopische, anorganische Formen in den erdigen und derben Mineralien, Bericht uber die Verhandlungen der Koniglich Preussichen Akademie der Wissenschaften, Berlin, 1836, 84-85, 1836.

Findlay, H., Tyrrell, T., Bellerby, R., Merico, A., and Skjelvan, I.: Ecosystem Modelling of the Norwegian Sea: investigating carbon and nutrients dynamics as a consequence of biological and physical processes, Biogeosciences Discuss., 4, 3229-3265, 2007 , http://www.biogeosciences-discuss.net/4/3229/2007/.

Furnas, M. J.: Net Insitu Growth-Rates of Phytoplankton in an Oligotrophic, Tropical Shelf Ecosystem, Limnol. Oceanogr., 36(1), 13-29, 1991.

Goyet, C., Bradshaw, A. L., and Brewer, P. G.: The carbonate system in the Black Sea, Deep-Sea Res., 38(Suppl. 2), S1049-1068, 1991.

Gripenberg, S.: On the alkalinity of Baltic waters, J. Conseil International pour l'Exploration de la Mer, 26, 1-20, 1960.

Gunnars, A., Blomqvist, S., and Martinsson, C.: Inorganic formation of apatite in brackish seawater from the Baltic Sea: an experimental approach, Mar. Chem., 91(1-4), 15-26, 2004.

Hallfors, G.: Checklist of Baltic Sea Phytoplankton Species, Baltic Sea Environment Proceedings, Helsinki Commission, Baltic Marine Environment Protection Commission, 201 pp., 2004.

Hay, B. J.: Sediment accumulation in the central western Black Sea over the past 5100 years, Paleoceanography, 3(4), 491-508, 1988.

HELCOM: Fourth periodic assessment of the state of the marine environment of the Baltic Sea, 1994-1998; background document, Baltic Sea Environmental Proceedings, 82B, 2002.

Hiscock, W. T. and Millero, F. J.: Alkalinity of the anoxic waters in the Western Black Sea, Deep-Sea Res. II, 53(17-19), 17871801, 2006.

Hjalmarsson, S., Wesslander, K., Anderson, L. G., et al.: Distribution, long-term development and mass balance calculation of total alkalinity in the Baltic Sea, Cont. Shelf Res., 28(4-5), 593601, 2008.

Holligan, P. M., Fernandez, E., Aiken, J., et al.: A biogeochemical study of the coccolithophore Emiliania huxleyi in the north Atlantic, Global Biogeochem. Cy., 7, 879-900, 1993.

Holligan, P. M., Groom, S. B., and Harbour, D. S.: What controls the distribution of the coccolithophore, Emiliania huxleyi, in the North Sea?, Fish. Oceanogr., 2(3/4), 175-183, 1993.

Humborg, C., Ittekkot, V., Cociasu, A., and VonBodungen, B.: Effect of Danube River dam on Black Sea biogeochemistry and ecosystem structure, Nature, 386(6623), 385-388, 1997.

Humborg, C., Pastuszak, M., Aigars, J., et al.: Decreased silica land-sea fluxes through damming in the Baltic Sea catchment - significance of particle trapping and hydrological alterations, Biogeochemistry, 77(2), 265-281, 2006.

Janssen, F., Schrum, C., and Backhaus, J. O.: A climatological data set of temperature and salinity for the Baltic Sea and the North Sea, German Journal of Hydrography, Supplement 9, 1999.

Key, R. M., Kozyr, A., Sabine, C. L., et al.: A global ocean carbon climatology: Results from Global Data Analysis Project (GLODAP), Global Biogeochem. Cy., 18(4), GB4031, doi:10.1029/2004GB002247, 2004.

Konovalov, S. K. and Murray, J. W.: Variations in the chemistry of the Black Sea on a time scale of decades (1960-1995), J. Marine Syst., 31(1-3), 217-243, 2001.

Kristiansen, S., Thingstad, T. F., Vanderwal, P., Farbrot, T., and Skjoldal, E. F.: An Emiliania-Huxleyi Dominated Subsurface Bloom in Samnangerfjorden, Western Norway - Importance of Hydrography and Nutrients, Sarsia, 79(4), 357-368, 1994.

Langer, G., Geisen, M., Baumann, K. H., et al.: Speciesspecific responses of calcifying algae to changing seawater carbonate chemistry, Geochem. Geophy. Geosy., 7, Q09006, doi:09010.01029/02005GC001227, 2006.

Larsson, U., Hajdu, S., Walve, J., and Elmgren, R.: Baltic Sea nitrogen fixation estimated from the summer increase in upper mixed layer total nitrogen, Limnol. Oceanogr., 46(4), 811-820, 2001.

Matishov, G., Matishov, D., Gargopa, Y., et al.: Climatic Atlas of the Sea of Azov 2006, U.S. Government Printing Office, Washington, D.C., 2006.

Mehrbach, C., Culberson, C. H., Hawley, J. E., and Pytkowicz, R. M.: Measurement of the apparent dissociation constant of carbonic acid in seawater at atmospheric pressure, Limnol. Oceanogr., 18, 897-907, 1973.

Merico, A., Tyrrell, T., and Cokacar, T.: Is there any relationship between phytoplankton seasonal dynamics and the carbonate system?, J. Marine Syst., 59(1-2), 120-142, 2006.

Mikaelyan, A. S., Pautova, L. A., Pogosyan, S. I., and Sukhanova, I. N.: Summer bloom of coccolithophorids in the northeastern Black Sea, Oceanology, 45(Suppl. 1), S127-S138, 2005.

Mucci, A.: The Solubility of Calcite and Aragonite in Seawater at Various Salinities, Temperatures, and One Atmosphere Total Pressure, Am. J. Sci., 283(7), 780-799, 1983.

Nanninga, H. J. and Tyrrell, T.: Importance of light for the formation of algal blooms by Emiliania huxleyi, Mar. Ecol.-Prog. Ser., 136(1-3), 195-203, 1996.

Oguz, T., Malanotte-Rizzoli, P., and Ducklow, H.: Simulations of phytoplankton seasonal cycle with multi-level and multilayer physical-ecosystem models: the Black Sea example, Ecol. Model., 144(2-3), 295-314, 2001.

Orr, J. C., Fabry, V. J., Aumont, O., et al.: Anthropogenic ocean acidification over the twenty-first century and its impact on calcifying organisms, Nature, 437(7059), 681-686, 2005.

Paasche, E.: A review of the coccolithophorid Emiliania huxleyi (Prymnesiophyceae), with particular reference to growth, coccolith formation, and calcification-photosynthesis interactions, Phycologia, 40(6), 503-529, 2001.

Pankow, H.: Ostsee-Algenflora, Gustav Fischer Verlag Jena, 648 pp., 1990.

Papush, L. and Danielsson, A.: Silicon in the marine environment: Dissolved silica trends, Estuar. Coast. Shelf S., 67(1-2), 53-66, 2006.

Pingree, R. D., Holligan, P. M., Mardell, G. T., and Harris, R. P.: Vertical-Distribution of Plankton in the Skagerrak in Relation to Doming of the Seasonal Thermocline, Cont. Shelf Res., 1(2), 209-219, 1982.

Pitsyk, G. K.: O kachestvennom sostave fytoplanktona Azovkogo morya (On the qualitiative composition of phytoplankton in the Sea of Azov), Sevastopol' Biol. Sta. Trudy, 16, 71-89, 1963. 
Rahm, L., Conley, D., Sanden, P., Wulff, F., and Stalnacke, P.: Time series analysis of nutrient inputs to the Baltic sea and changing DSi:DIN ratios, Mar. Ecol.-Prog. Ser., 130(1-3), 221-228, 1996.

Raitsos, D. E., Lavender, S. J., Pradhan, Y., et al.: Coccolithophore bloom size variation in response to the regional environment of the subarctic North Atlantic, Limnol. Oceanogr., 51(5), 21222130, 2006.

Rost, B. and Riebesell, U.: Coccolithophore calcification and the biological pump: response to environmental changes, in: Coccolithophores: from molecular processes to global impact, edited by: Thierstein, H. R. and Young, J. R., Springer, Berlin, 99-126, 2004.

Roy, R. N., Roy, L. N., Vogel, K. M., et al.: The disssociation constants of carbonic acid in seawater at salinities 5 to 45 and temperatures 0 to 45 deg C, Mar. Chem., 44, 249-267, 1993.

Schneider, B. and Kuss, J.: Past and present productivity of the Baltic Sea as inferred from $\mathrm{pCO}(2)$ data, Cont. Shelf Res., 24(15), 1611-1622, 2004.

Schneider, B., Nausch, G., Nagel, K., and Wasmund, N.: The surface water $\mathrm{CO}_{2}$ budget for the Baltic Proper: a new way to determine nitrogen fixation, J. Marine Syst., 42(1-2), 53-64, 2003.

Siesser, W. G.: Historical background of coccolithophore studies, in: Coccolithophores, edited by: Winter, A. and Siesser, W. G., Cambridge University Press, Cambridge, 1-12, 1994.

Smyth, T. J., Tyrrell, T., and Tarrant, B.: Time series of coccolithophore activity in the Barents Sea, from twenty years of satellite imagery, Geophys. Res. Lett., 31(11), L11302, doi:10.1029/2004GL019735, 2004.

Takahashi, T., Olafsson, J., Broecker, W. S., et al.: Seasonal variability of the carbon-nutrient chemistry in the ocean areas west and north of Iceland, in: Chemical Tracers for Studying Water Masses and Physical Processes in the Sea, edited by: Stefansson, U., Journal of the Marine Resarch Institute, Reykjavik, 20-36, 1985.
Tyrrell, T. and Merico, A.: Emiliania huxleyi: bloom observations and the conditions that induce them, in: Coccolithophores: from molecular processes to global impact, edited by: Thierstein, $\mathrm{H}$. R. and Young, J. R., Springer, Berlin, 75-97, 2004.

Tyrrell, T. and Taylor, A. H.: A modelling study of Emiliania huxleyi in the NE Atlantic, J. Marine Syst., 9(1-2), 83-112, 1996.

Wasmund, N., Nausch, G., and Matthaus, W.: Phytoplankton spring blooms in the southern Baltic Sea - spatio-temporal developments and long-term trends, J. Plankton Res., 20, 1099-1117, 1998.

Weiss, R. F.: Carbon dioxide in water and seawater: The solubility of a non-ideal gas., Mar. Chem., 2, 203-215, 1974.

Winter, A., Jordan, R. W., and Roth, P. H.: Biogeography of living coccolithophores in ocean waters, in: Coccolithophores, edited by: Winter, A. and Siesser, W. G., Cambridge University Press, Cambridge, 161-178, 1994.

Wulff, F. and Rahm, L.: Long-Term, Seasonal and Spatial Variations of Nitrogen, Phosphorus and Silicate in the Baltic - an Overview, Mar. Environ. Res., 26(1), 19-37, 1988.

Young, J. R.: Functions of coccoliths, in: Coccolithophores, edited by: Winter, A. and Siesser, W. G., Cambridge University Press, Cambridge, 63-82, 1994.

Zeebe, R. E. and Wolf-Gladrow, D.: $\mathrm{CO}_{2}$ in Seawater: Equilibrium, Kinetics, Isotopes, Elsevier Oceanography Series, 65, Elsevier, Amsterdam, 360 pp., 2001. 